\title{
Power and ambition: Georg Rhau's strategies for music publishing
}

Moritz Kelber

There is almost no fundamental study on the Reformation that does not emphasise the importance of printing for the movement's success: the printing press first made Martin Luther famous beyond a narrow theological context. ${ }^{1}$ In the early years of the Reformation, Wittenberg became a centre of printing and publishing, despite lacking basic preconditions for success. ${ }^{2}$ Lying in the Empire's North-East, it was far from major trading routes, unlike cities such as Augsburg, Nuremberg, Frankfurt or Mainz. Although Luther and his circle complained about the problems caused by Wittenberg's isolation, they succeeded in establishing Wittenberg as a unique place - a unique brand - in the printing and publishing market. $^{3}$

Even before Luther's Reformation transformed the printing industry across the Empire, a fledgling printing industry existed in Wittenberg. Its motor was the university, founded by Elector Friedrich III ('the Wise') of Saxony in 1502, to serve mainly as a centre for the education of administrative staff. ${ }^{4}$ Early Wittenberg printers such as Nikolaus Marschalk, who produced the first printed book in Wittenberg in December 1502, or Wolfgang Stöckel, the first official university printer, produced their books mainly for local educational purposes. The first printer in Wittenberg who published music was Johannes Grunenberg. ${ }^{5}$ In 1508, he was invited by Johannes von Staupitz (c. 1465-1524), one of the founders of the university, to establish a printing workshop. In 1511, Grunenberg printed a small pamphlet containing a piece for four voices, a student drinking song in humanistic fashion, with woodblocks of low quality. ${ }^{6}$

This chapter focusses on Georg Rhau, one of the key figures of Wittenberg printing in the first half of the sixteenth century. Rhau was not only one of the most productive printers of theological and propagandistic literature of his time, but also the most active music printer. The first part of this chapter presents general observations about Rhau's activities as a music printer, based mainly on the data collected by the $v d m$ team. ${ }^{7}$ The paper then focusses on Rhau's polyphonic music books, outlining Rhau's efforts to use the Wittenberg brand to market polyphonic music books. The third part presents new evidence about polyphonic music books produced for special occasions, a genre that has been largely neglected by musicological scholarship. Finally, the fourth part of this chapter discusses a lost polyphonic music book by Rhau that prompts some questions about the role of this genre in the music printing industry.

\section{Georg Rhau and his printing workshop}

Georg Rhau is an exceptional figure in early modern music printing for many reasons, not least for his musical education. He was born in 1488 in the central German town of Eisfeld, 
and studied at Erfurt and Wittenberg from 1508 to 1514. For about four years, he worked in the printing workshop of Johann Grunenberg at Wittenberg. Between 1518 and 1520, he was cantor of St Thomas's Church in Leipzig, and taught music theory at the University of Leipzig. In 1519, Rhau's twelve-voice Missa de Sancto Spirito opened the disputation between Martin Luther and Johannes Eck. ${ }^{8}$ After only two years Rhau had to leave Leipzig, apparently because of his sympathies for Luther and his teachings. Before he moved back to Wittenberg to start his career as printer and publisher in 1523, he worked for a short time as schoolmaster in Eisleben and Hildburgshausen. ${ }^{9}$

Although it is uncertain when Rhau gained access to Luther's circle, he had established close personal connections to many key figures of the Reformation by the time he started publishing books under his own name. Given Rhau's role as a key agent of the Reformation and one of the most important printers and publishers of music in sixteenth-century Germany, it is not surprising that scholarship has developed a lively interest in his activity, although most accounts of his biography are still based on the early research of Willy Woelbing. ${ }^{10}$ Marie Schlüter, Jürgen Heidrich and Victor H. Mattfeld have mainly concentrated on Rhau's role as music editor and publisher. ${ }^{11}$ Perhaps the most spectacular recent development in Rhau scholarship comes from the field of archaeology. Recent excavations in the city centre of Wittenberg have revealed pieces of metal type from the sixteenth century, some of which are from a music font. Most were found within the former Franciscan monastery, home to several printing workshops after the cloister was abandoned in 1522 . Georg Rhau moved his printing workshop to these buildings in 1538. The discovery of original music type used by Rhau has not only sharpened the understanding of his production processes but has also provided a better understanding of the particularities of his music books. ${ }^{12}$

As is the case with most other printers in fifteenth- and sixteenth-century Germany, most of Georg Rhau's books did not contain musical notation. However, music printing was a key element in his marketing strategy. In a publication of Mass propers from 1545, he explicitly refers to himself as a music printer ('musicae typographus'). ${ }^{13}$ The production of music books in Rhau's printing workshop was shaped by the demands of a market formed by the Reformation. It also surpassed other printing firms both in the extent of its forward planning of series of publications, and its vicinity to the political elites. The publication programme of Rhau's firms was also influenced deeply by his own personal interests and expertise, especially in music theory. During the period of his activity (1525-1548), Rhau was responsible for more than $40 \%$ of all music-theory books containing musical notation that were printed in German-speaking lands. ${ }^{14}$ Among these were nine editions of Nicolaus Listenius' school music-theory treatise. ${ }^{15}$ Of the ninety-five known musical editions published by Rhau's firm during its founder's life, more than half are music-theory books, including first and later editions.

The year 1538 was a turning point in Rhau's career. In this year he moved his printing workshop to the abandoned buildings of the old Franciscan monastery in Wittenberg, and created his own single-impression type for printing music. ${ }^{16}$ Until that point he had used only woodcut to print musical notation. The design of Rhau's music font was derived from Hieronymus Formschneider's successful type. Donald Krummel assumed that Rhau bought them directly from Nuremberg. ${ }^{17}$ However, Daniel Berger and his colleagues have argued that the Wittenberg printer most likely purchased the punches and matrices from Formschneider to produce his own letters. ${ }^{18}$ The similarities between the two typefaces are striking. Like the Nuremberg printer, Rhau uses a distinctive g-clef that resembles an ' $E$ '. Both use a rectangular c-clef placed outside the system, and both print the accidentals on 
the staff lines. Breves and longs are printed with serifs in both typefaces. The differences between Rhau's and Formschneider's typefaces are limited to minor typometric differences. ${ }^{19}$ Formschneider's single-impression music books look slightly neater because of his exceptionally careful alignment of type.

From 1538, most of Rhau's music books were printed in single-impression technique. He used his music type not only for polyphonic music books, but also for other genres. However, for re-issues of books first published before 1538, he continued to use the old woodblocks. ${ }^{20}$ Printing polyphonic music became a cornerstone of Georg Rhau's company. ${ }^{21}$ However, the preparations for the endeavour took some time. In the preface to Listenius' Rudimenta musicae of 1533, Johannes Bugenhagen mentions that Rhau was soon to print music by Josquin and others ('quam primum aediturum insignibus characteribus, carmina IOSQVINI \& aliorum'). ${ }^{22}$ Wolfgang Reich assumes that it might have taken Rhau a considerable amount of time to collect music and make preparations for the numerous editions which were published very quickly. ${ }^{23}$ In only eight years, between 1538 and 1545, Rhau printed twenty editions containing polyphony, making him the most productive German music printer of that genre in the first half of the sixteenth century (see Table 5.1).

Most of Rhau's polyphonic publications contain exclusively sacred repertoire. Together, they represent a massive project to disseminate an extensive repertoire of sacred polyphony

Table 5.1 Polyphonic music books printed by Georg Rhau between 1538 and 1545

\begin{tabular}{llll}
\hline $\mathbf{v d m}$ & Title & Year & Dedicatee \\
\hline 36 & Selectae harmoniae quatuor vocum de passione domini & 1538 & - \\
40 & Symphoniae iucundae atque adeo breves & 1538 & - \\
46 & Officia paschalia de resurrectione et ascensione domini & 1539 & Jodocus Schalreuter \\
$49 / 1555 a$ & Vesperarum precum officia psalmi feriarum et & 1540 & City council of Coburg \\
& dominicalium dierum & & \\
1019 & Opus decem missarum quatuor vocum & 1541 & City council of Torgau \\
1145 & Novum ac insigne opus musicum triginta sex & 1541 & Church and school of \\
& antiphonarum & & Wittenberg \\
1023 & Tricinia tum veterum tum recentiorum & 1542 & City council of \\
& & & Hilpertshausen \\
1024 & Sacrorum hymnorum liber primus & 1542 & City council of \\
& & & Joachimsthal \\
1159 & Responsoriorum numero octoginta & 1543 & - \\
1028 & Magnificat octo modorum & 1544 & Johann Goskau \\
1029 & Newe deutdsche geistliche Gesenge CXXIIII & 1544 & City council of Eisfeld \\
1158 & Wittembergisch deudsch geistlich Gesangbüchlein & 1544 & - \\
1160 & Responsoriorum numero octoginta & 1544 & - \\
1161 & Cantio septem vocum & 1544 & Johann Friedrich of \\
& & & Saxony \\
1162 & Novum opus musicum & 1544 & Melchior Kling \\
1035 & Officiorum de Nativitate & 1545 & Nikolaus Kind \\
1036 & Secundus tomus biciniorum & 1545 & Caspar Hemel \\
1163 & Bicinia gallica, latina, germanica & 1545 & Johannes Hemel \\
1504 & Novum opus musicum & 1545 & Melchior Kling \\
1517 & [Motet for seven voices] & 1545 & [City council of \\
& & & Annaberg?] \\
\hline & & &
\end{tabular}

${ }^{a} v d m$ lists two separate editions of the Vesperarum precum officia (vdm 49 and vdm 1555), which contain minor variants in the first gathering. 
for use within the Protestant liturgy and beyond. Heidrich argues that, although liturgical repertoire dominates Rhau's publications, the institutional focus is clearly on the Protestant school milieu. ${ }^{24}$ Indeed, churches and schools in many Protestant and Catholic cities formed a symbiotic organism. After Rhau's death in 1548, his heirs continued printing until the mid-1560s. However, they stopped printing polyphonic music in 1550 with the Epitaphia Rhauorum, a musical epitaph for various members of the Rhau family, composed by the young musician Johann Reusch. ${ }^{25}$

\section{Marketing polyphonic music from Wittenberg}

Georg Rhau's polyphonic music books combine German and international repertoire. Most of the composers form a Lutheran canon, from Josquin des Prez to Ludwig Senfl, and including unambiguously Protestant composers such as Johann Walter and Sixt Dietrich. However, the editor Rhau crossed confessional boundaries by drawing directly from Italian music books. For his 1544 collection of Magnificats (vdm 1028), he directly copied an anthology published two years earlier by Scotto in Venice. ${ }^{26}$ Several times Rhau stated on title pages and in paratexts that he wished to make available an extensive polyphonic repertoire for schools and churches alike. For liturgical use he published a series of six collections of polyphony for vespers and three anthologies containing polyphonic settings of the Mass ordinary and propers. ${ }^{27}$ The collections of bicinia (vdm 1163 and 1036), tricinia (vdm 1023), Latin motets (vdm 40, 1504, 1162), and German hymns (vdm 1029) are explicitly or implicitly directed to educational purposes.

Rhau created an exceptional consistency of his publications through repertoire, paratexts and imagery. His close contacts to Martin Luther and his Wittenberg circle enabled him to win prominent reformers such as Philipp Melanchthon, Johannes Bugenhagen, and even Luther himself as authors for paratexts in his music books. Epigrams, addresses to the readers, and extensive prefaces were key elements in Rhau's marketing strategy and instruments of Protestant authorisation. ${ }^{28}$ The two 1538 editions that mark the beginning of Wittenberg polyphonic music printing contain prefaces by Martin Luther (vdm 40) and Philipp Melanchthon (vdm 36) instead of dedicatory letters. Both reformers contributed liminal texts in polyphonic music books alongside other famous Lutherans such as Johann Spangenberg and Johann Bugenhagen.

From 1540 onwards, almost all polyphonic music books from the Rhau workshop were published with a dedication to an individual or an institution (see Table 5.1). City councils in Ernestine or Albertine Saxony dominate: Coburg, Wittenberg, Torgau, Eisfeld, Hildburgshausen, Freiberg, and presumably Annaberg. The motet collection Sacrorum hymnorum liber primus (vdm 1024) is dedicated to the city council of the mining town Joachimsthal (now Jáchymov), close to the Saxon border. Although Rhau included dedications in other kinds of music books as well, urban institutions were the exclusive dedicatees of publications containing polyphonic music. The probable motive for addressing city councils in polyphonic music books was their responsibility for local schools. This link becomes obvious in the first dedicatory letter by Rhau to a city council, included in the Vesperarum precum officia psalmi (vdm 49 and 1555), a collection of mainly simple polyphony. The text deals with educational issues right from the start:

It was always my highest endeavour, most wise and distinguished men, that I should benefit schoolboys first and foremost through my printing workshop. Thus, for the past few years, I have neglected more serious authors and primarily taken on the special task of printing basic handbooks of the arts for children. Led on by this same reason, I have decided now to 
print with metal type the psalm-tones appropriate for weekdays use, or four voices in simple counterpoint, with the melodies varied as necessary, of the sort we are accustomed to sing in church to give the boys good practice both on weekdays and on Sundays. ${ }^{29}$

Rhau added a second letter at the end of the book, this time addressed to 'all learned and faithful schoolmasters' ('omnibus eruditis \& fidelibus Ludimagistris'), further underlining the pedagogical ambition of this publication. When evaluating Rhau's strategy for addressing dedications, one must remember that he himself was a member of the council in Wittenberg from 1541 on. Thus, dedicating a book to the council of another city was an explicitly political act.

Rhau dedicated other polyphonic music books to individuals from his own private circle. Jocodus Schalreuter, the dedicatee of the Officia paschalia from 1539 (vdm 46), was cantor of the Ratsschule in Zwickau. ${ }^{30}$ In the dedicatory letter, Rhau thanked the kindly and musically experienced ('humanissimo, musicaeque peritissimo viro') Schalreuter for his help during the preparation of the book. The 1544 collection of Magnificats (vdm 1028) is dedicated to Johann Goskau, a scribe in Jessen, a town close to Wittenberg, whom Rhau addressed as a familiar and very dear friend ('Familiari ac amico suo longe charissimo'). The dedicatory letter to Goskau maintains an extraordinarily personal tone. The first volume of Rhau's Bicinia (vdm 1163) is dedicated to Johannes Hemel, while the second (vdm 1036) addresses his son, Caspar. ${ }^{31}$ There is very little information about Hemel's biography except that he studied in Wittenberg and in 1556 published a rhymed German paraphrase of the seven Penitential Psalms (VD16 B 3529). The dedication of Sixt Dietrich's Novum opus musicum (vdm 1162 and 1504), first issued on 1544, is of special political relevance. The dedicatee, Melchior Kling, who acted as an advisor to the Saxon Elector from 1542, was accused by Martin Luther of being an agent of papal authority in 1544, and fell into the disfavour of Elector Johann Friedrich. ${ }^{32}$ When the Novum opus musicum was re-issued in 1545, right at the climax of the conflict, the same dedicatory letter was included. Although the dedicatory letter was written by Sixt Dietrich, who lived in Constance and was probably not aware of all the theological and political conflicts in Wittenberg (even though he had spent some time there), it remains unclear why Rhau, a close friend of Luther, published a dedicatory letter to this controversial figure even after he had fallen into disgrace.

In his instructive analysis of Rhau's Latin dedicatory letters, Raimund Redeker outlines the importance of the dissemination of Lutheran repertoire in schools, churches and small parishes against the possible economic interests of the music publisher Rhau. Taking Rhau's prefaces and dedications and their topoi of modesty literally, Redeker even speculates about an intentional self-limitation concerning commercial success. ${ }^{33}$ Since we know so little about Rhau's business model, we can only guess about his economic success. As Royston Gustavson has pointed out, he clearly had a different strategy from that of his colleagues from Frankfurt, Augsburg, Strasbourg and Nuremberg, in that he aimed explicitly at a Protestant audience. ${ }^{34}$ The development of this overtly evangelical marketing strategy is obvious in the evolving visual imagery of the polyphonic collections printed at Wittenberg. Most of Rhau's editions have highly decorated title pages. In most cases, the title page of the tenor partbooks varies from that of the other voices. The first polyphonic music books from the Rhau printing workshop have a remarkably standardized appearance. Almost all editions published until 1542 use the same framing title woodcut, which depicts various musical instruments (see Figure 5.1). ${ }^{35}$ Starting in 1542 with the Sacrorum hymnorum liber primus (vdm 1024), Rhau began to employ explicitly Protestant imagery. The title page of the tenor partbook of this collection shows the emblems of five Reformers in round garlands: Luther's rose, Johann Bugenhagen's harp, the elevated snake of 
Melanchthon, Justus Jonas' symbol of the whale, and the dove of Caspar Cruciger (see Figure 5.2). Rhau re-used this design for three further anthologies (vdm 1029, 1159, 1160). From 1544 he employed a second layout for his title pages, which was likewise clearly political. The tenor partbook of the collection Magnificat octo modorum (vdm 1028) shows portraits of Martin Luther, Elector Johann Friedrich of Saxony, and Philipp Melanchthon in medallions (see Figure 5.3). The printer re-used the same design for the two editions of his Novum opus musicum (vdm 1162, 1504). For the tenor title page of the anthology Officiorum (ut vocant) de Nativitate (vdm 1035), Rhau only used the upper half of this layout, which is decorated with woodcut acanthus decorations and three medallions displaying Luther's rose, two crossed swords for the Elector of Saxony, and Melanchthon's snake. The lower half of the title page displays the canting arms of the publication's dedicatee, Nicolaus Kind (see Figure 5.4). Most of Rhau's collections of polyphony have an explicitly Electoral Saxon appearance, either through a woodcut coat of arms or even a portrait of the Elector Johann Friedrich himself. ${ }^{36}$ Although Rhau dedicated only one edition to the Elector, his persistent use of Electoral Saxon imagery marks his music publishing as a 'national' enterprise. Woelbing suggested that the depiction of the Elector's arms and portrait had a function similar to a printing privilege. In evidence, Woelbing cites a letter by the theologian Georg Major to the King of Denmark:

At the forthcoming Autumn Fair, we want to buy paper for bibles, and to negotiate with Hans Lufft so that he might start printing soon after Michaelmas etc. Furthermore, we ask Your Grace to excuse us to the Elector and to ask him that he may graciously confirm our old privilege for our books, so that we should not be afraid of any reprints. We would take special care to have a woodcut portrait of the Elector designed and cut in the best way possible, and to print it next to the privilege at the beginning of the bible, in the same manner as we did with the old Elector Johann Friedrich, with his Grace's permission and to his pleasure. We are comforted by the hope that the Elector will graciously protect us as his subjects and maintain us in our old rights [...]. 15 July $1558 .{ }^{37}$

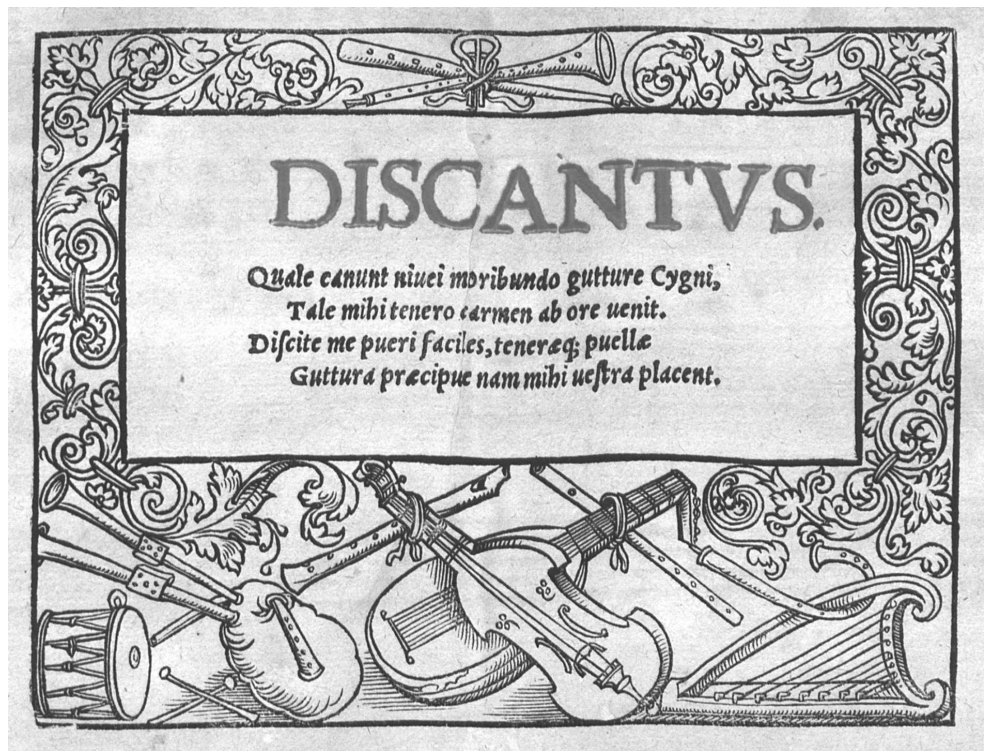

Figure 5.1 Title page of discantus partbook from Rhau's Symphoniae iucundae atque adeo breves (vdm 40).

Source: Munich, Bayerische Staatsbibliothek, Mus.pr. 12. 


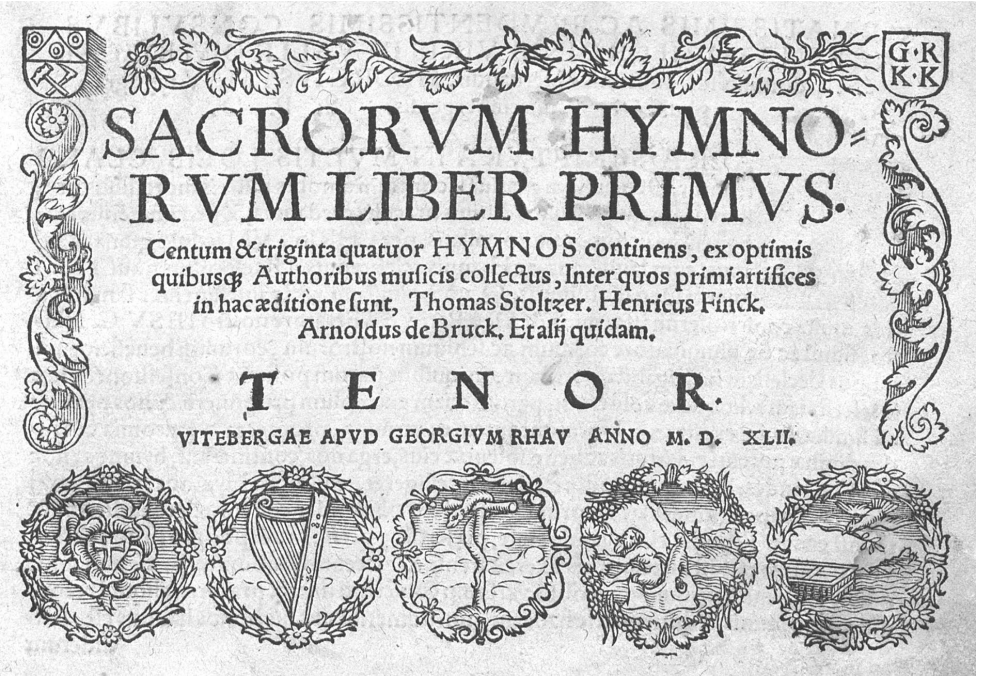

Figure 5.2 Title page of tenor partbook from Rhau's Sacrorum hymnorum liber primus (vdm 1024). Source: Munich, Bayerische Staatsbibliothek, Mus.pr. 9590.

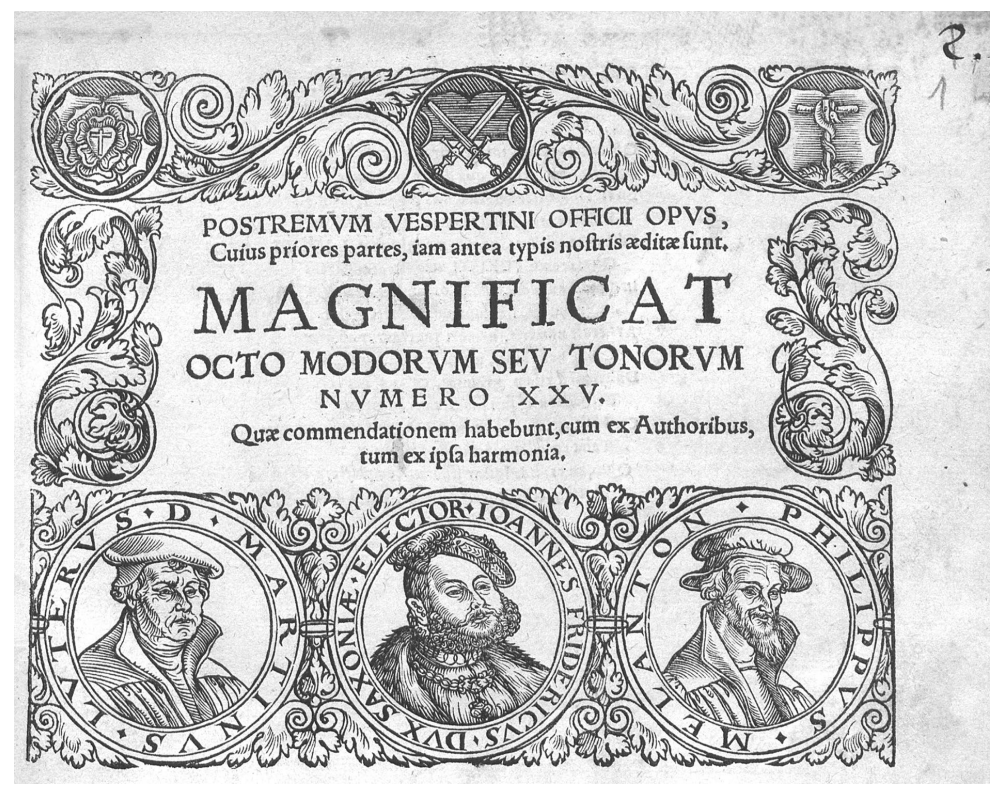

Figure 5.3 Title page of tenor partbook from Rhau's Magnificat octo modorum (vdm 1028). Source: Munich, Bayerische Staatsbibliothek, 4 Mus.pr. 175\#Beibd.1.

There is no evidence that Rhau possessed such a privilege from the Elector; likewise it remains unclear whether the political imagery could have served as a surrogate privilege. In the Saxon Electorate, which would have been the scope of an Electoral privilege, Georg Rhau dominated the production of polyphonic music books. Polyphonic music printing was a highly specialized business, in which few printers dared to invest during the first 


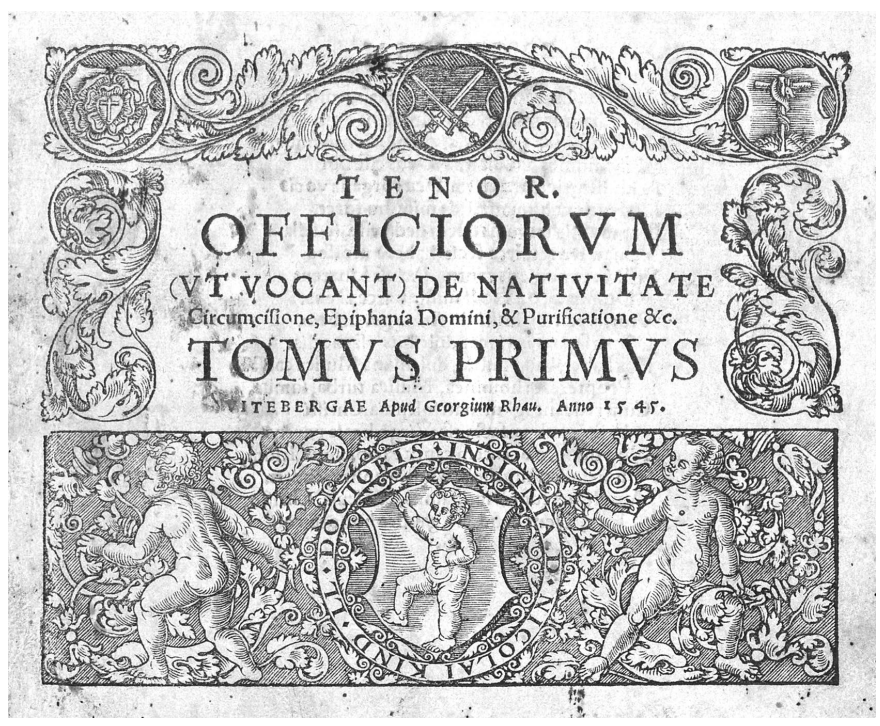

Figure 5.4 Title page of tenor partbook from Rhau's Officiorum de Nativitate (vdm 1035). Source: Berlin, Staatsbibliothek, Mus.ant.pract. R460.

half of the sixteenth century. Thus, it is at least questionable if Rhau needed legal protection by a privilege at all. ${ }^{38}$

Georg Rhau's marketing strategy was clearly aimed at an orthodox Lutheran audience. Judging from the repertoire included in most of the anthologies, one might wonder why the editor did not follow the example of his colleagues in Nuremberg or Augsburg, who chose to publish music collections attractive to Catholics and Protestants alike. Evidence of antipathy towards the Lutheran message among some of those who owned or used copies of Rhau's books can be seen in one copy of the Novum opus musicum of 1544 (vdm 1162), which perhaps belonged to the monastery of SS Ulrich and Afra in Augsburg, or in any case to a Catholic interested in the music but disturbed by the imagery; this reader has conscientiously blacked out the three medallions of Luther, Elector Johann Friedrich and Melanchthon (see Figure 5.5).

Concerning the repertoire, Rhau's orthodoxy had its limits. The 1542 hymn collection Sacrorum hymnorum liber primus (vdm 1024) contains a detailed excuse for having included hymns intended for feasts not recognised by the Lutheran church:

In these past few days we have [...] here in our printing workshop finished the Liber primus sacrorum Hymnorum, in which we collected 134 hymns, both de tempore and de sanctis, which are outstanding not only for their suavity and sweetness, but also for their brevity and ease of execution. As we were giving the finishing touches to this anthology, [...] it occurred to us how malicious the judgments of many are, in the perverse age in which we live. Because our holy church of Wittenberg forbids the invocation of saints and other idolatrous forms of worship, whenever they discover hymns about certain Saints in this our collection that are not in conformity with the theological meaning of Scripture, perchance immediately clamour that I want to restore or approve the old impieties. For this reason, we affirm with this letter that we, like all pious people, despise all dogmas inconsistent with the writings of the prophets and apostles. Thus, if there are hymns concerning the Saints in this collection that are inconsistent with the harmony of the Holy Scripture, the reader should remember that they have been added because of the suavity of the music and to give boys practice in singing. Let us not dwell on the so-called idolatrous texts, but condemn them. ${ }^{39}$ 


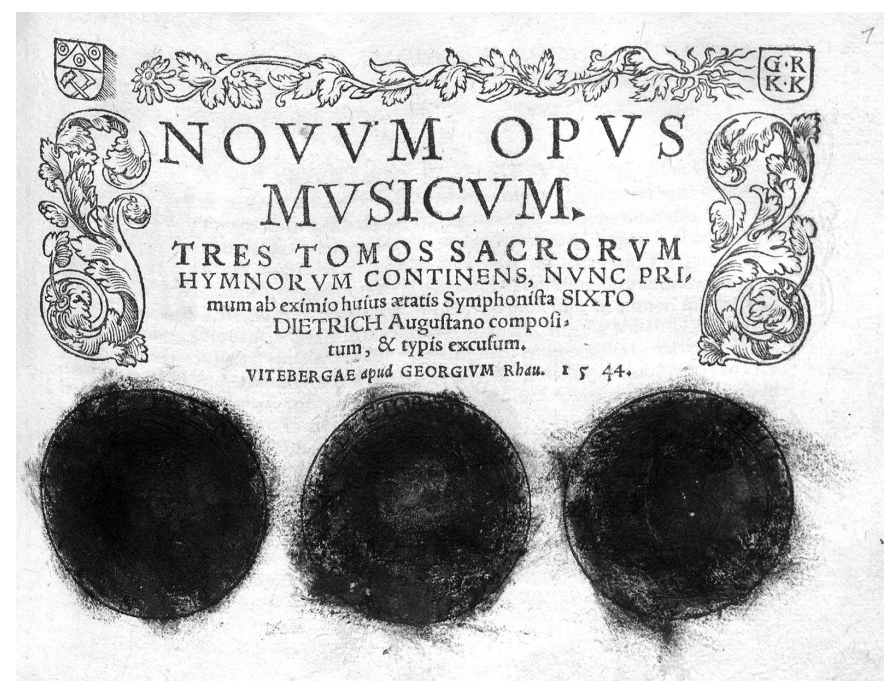

Figure 5.5 Title page of Tenor partbook from Rhau's Novum opus musicum (vdm 1162). Source: Augsburg, Staats- und Stadtbibliothek, Tonk Schl 400-403.

The liminal texts to Georg Rhau's polyphonic music books paint a picture of turbulent times, when even the members of the inner circle disagreed about liturgical key questions, such as the role of responsories during Lutheran services. ${ }^{40}$

It is difficult to judge Rhau's economic success in publishing polyphonic music. The extant historical catalogues of contemporary libraries indicate that he sold books to many churches and schools in his core market, the Protestant regions in the North-East of the Empire. ${ }^{41}$ The sixteenth-century Ratsschulbibliothek in Zwickau, for example, possessed most of the polyphonic music printed in Wittenberg before $1550 .{ }^{42}$ However, that observation might relate to the close personal relationship between Rhau and Jocodus Schalreuter, the Cantor at the Ratsschule in Zwickau.

Today the Ratsschulbibliothek in Zwickau and the British Library hold the largest collections of Rhau's polyphonic music books. The London editions were acquired by the library from Berlin booksellers in the nineteenth century. ${ }^{43}$ Other surviving copies of Rhau's publications are traceable to institutions in Leipzig, Bitterfeld, Görlitz, Meißen and elsewhere. ${ }^{44}$

Georg Rhau ceased producing polyphonic music books in 1545. It is possible that his programme of publishing liturgical polyphony for the Lutheran rite was complete after eight years of activity. Alternatively, his further plans may have been frustrated by the outbreak of the Schmalkaldic War in July 1546, and the attendant shifts in political priorities. His firm continued to print music books, though it now focussed on broadsheets and pamphlets, such as the monophonic Vermanlied of 1546 (vdm 1339), which deals with events of the war. There are indications that Georg Rhau even had to provide a mobile printing press for the campaigns of the Saxon Elector. ${ }^{45}$ It is also possible that the end of Rhau's programme of printing polyphony was caused by the frail health to which he alluded in the dedicatory letter to Johannes Goskau in $1544 .^{46}$ 


\section{Publications containing polyphonic music for special occasions}

In the tense political climate of the 1540s, the printing of political, polemical, and propagandistic pamphlets and broadsheets reached a peak. Many used music as a tool to transport their message. ${ }^{47}$ Although religion dominated ideological conflicts, publications containing occasional music - sometimes even polyphonic music - arose in other contexts as well. Between 1530 and 1550, several short publications in partbook format appeared, many containing only one piece, associated with a single person, a group of people, an institution, or an occasion (see Table 5.2). The partbooks were printed in the same format as the larger anthologies, and could thus easily be bound in a composite volume with other editions. Three such editions were produced in the Rhau printing workshop in Wittenberg; one of these has been unknown in musicological scholarship to this point.

Probably the most famous book in this small group is the Epitaphia Rhauorum (vdm 1154), a musical epitaph for various members of the Rhau family published in 1550 by Georg Rhau's heirs after his death. The compositions were written by Johann Reusch, a young musician who studied at the University of Wittenberg in the early 1540s. Because of its importance for the biography of Georg Rhau, this book has already received some scholarly attention, and thus will not be further considered here. ${ }^{48}$

Another well-known set of short partbooks from the Rhau workshop was printed in 1544. It contains one motet for seven voices, in five partes (Cantio septem vocum), written for the dedication of the chapel in Schloss Hartenfels, Torgau. ${ }^{49}$ The composer of this extraordinary piece was Johann Walter, who directed the Torgau chapel at that time. ${ }^{50}$ The composition was performed during the consecration of the chapel on 5 October $1544 .^{51}$ Martin Luther himself delivered the sermon in the presence of Elector Johann Friedrich and Philipp Melanchthon..$^{52}$ The published edition of the Cantio comprises a synopsis of the political symbolism of the polyphonic music books that Rhau had published to that point.

The music is printed in four partbooks, each with at most six leaves. The choice of seven voices is rare in the oeuvre of Walter, found in only two motets. ${ }^{53}$ The visual design of the title pages clearly expresses the political context. Three partbooks are decorated with the arms of the Saxon Elector (see Figure 5.6), framed by a floral wreath, while the main title page has a poem honouring the dedicatee. Woodcut portraits and symbols of the Elector, of Martin Luther and of Philipp Melanchthon, printed on several pages inside the partbooks, emphasise the political context. ${ }^{54}$ Rhau did not produce any new woodcuts for the Cantio septem vocum, but re-used portraits, coats of arms and symbols from other editions. The partbooks thus are not only the expression of the political symbolism of this one important event: they are embedded in a larger iconographical programme. ${ }^{55}$

Table 5.2 Sets of short partbooks (containing a single or few mostly occasional compositions) printed in German-speaking lands until 1550

\begin{tabular}{lllll}
\hline vdm & Title & Year & Printer & Place \\
\hline 62 & $\begin{array}{l}\text { Epicedion Thomae Sporeri musicorum } \\
\text { principis }\end{array}$ & 1534 & $\begin{array}{l}\text { Peter Schöffer the Younger \& } \\
\text { Matthias Apiarius }\end{array}$ & Strasbourg \\
1517 & [Motet for seven voices] & 1545 & Georg Rhau & Wittenberg \\
1161 & Cantio septem vocum & 1544 & Georg Rhau & Wittenberg \\
1038 & Epitaphium D. Martini Lutheri & 1546 & Berg \& Neuber & Nuremberg \\
1154 & Epitaphia Rhauorum & 1550 & Georg Rhau's heirs & Wittenberg \\
1139 & $\begin{array}{l}\text { Proteleios euche qua chorus musicus } \\
\text { bene precatur }\end{array}$ & c. 1550 & Berg \& Neuber & Nuremberg \\
\hline
\end{tabular}


Although the four tenor voices are strictly canonic, and could have been easily notated in a single partbook, Rhau and Walter decided to print the canon's resolution, which meant notating each part separately. The decision for four instead of the necessary two partbooks is - beside representative needs - most likely determined by the necessity of binding such a short set into another larger composite volume.

The most striking characteristic of Walter's motet is probably its polytextuality: three different texts are sung at the same time. The canonic voices and the discantus sing the words of Psalm 119. The altus and bassus, however, convey the composition's political message. The former, illustrated with three woodcut portraits of the Elector, praises Johann Friedrich as defender of true religion and peace. The latter, decorated with portraits and symbols of Martin Luther and Philipp Melanchthon, honours the two Reformers as luminaries (see Table 5.3). The text is set under two corresponding 'melodic' lines. The bassus alternates between $c$ and $G$, while the altus voice has an ostinato $g^{\prime}$.

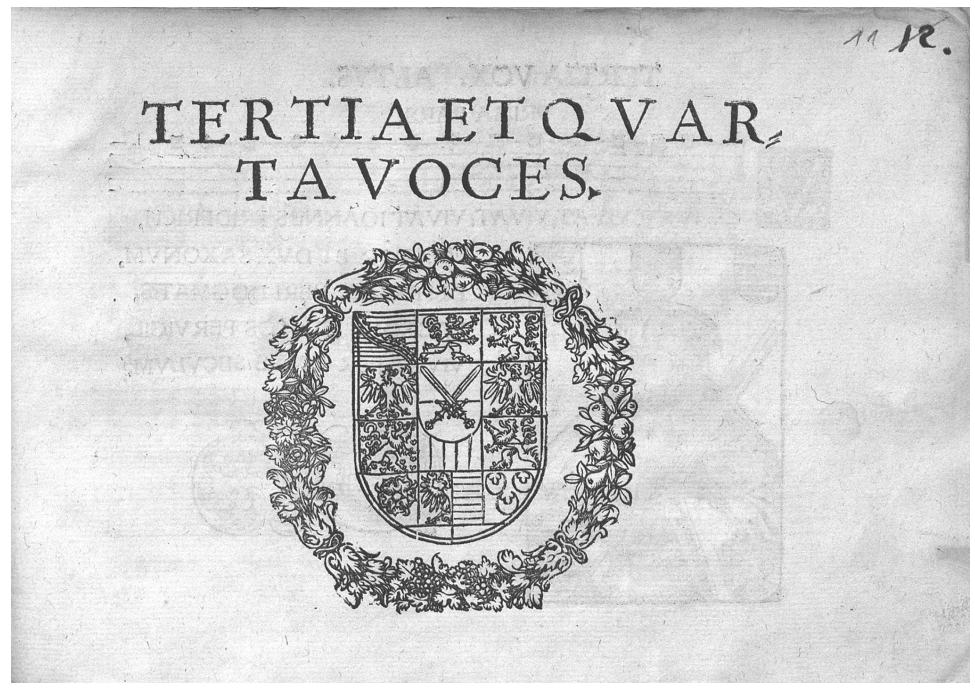

Figure 5.6 Title page of tertia et quarta voces partbook from Rhau's Cantio septem vocum (vdm 1161). Source: Munich, Bayerische Staatsbibliothek, 4 Mus.pr. 106\#Beibd.11.

Table 5.3 Text of Johann Walter's Cantio septem vocum (vdm 1161), Psalm 119 (118)

\section{Discantus and canonic voices}

(1) Beati immaculati in via, qui ambulant in lege Domini.

(2) Beati qui scrutantur testimonia eius, in toto corde exquirunt eum. (5) Utinam dirigantur viae meae, ad custodiendas iusificationes tuas. (6) Tunc non confundar cum perspexero in omnibus mandatis tuis. (12) Benedictus es Domine, doce me iustificationes tuas. (35) Deduc me in semita mandatorum tuorum, quia ipsam volui. (36) Inclina cor meum in testimonia tua, Et non in avaritiam. (37) Averte oculos meos, ne videant vanitatem, in via tua vivifica me. (171) Eructabunt labia mea Hymnum, cum docueris, iustificationes tuas. (175) Vivet anima mea et laudabit te, et iudicia tua adiuvabunt me.

Bassus Altus

Vive Luthere, Vive Melanthon, Vivite nostrae Lumina terrae, Charaque Christo Pectora, per vos Inclyta nobis Dogmata Christi Reddita, vestro Munere, pulsis Nubibus atris, Prodiit ortu Candidiore Dogma salutis, Vivite longos Nestoris annos. Amen.
Vivat Joannes Friderich, Vivat Elector et Dux Saxonum, Vivat Defensor veri dogmatis, Vivat Pacisque custos pervigil, Vivat per omne seculum. 
This results in a quite static musical texture which is rhythmically and harmonically limited (Example 5.1).

\section{Example 5.1}

Beginning of Walter's setting of Psalm 119, from Johann Walter, Sämtliche Werke, vol. 5, edited by Max Schneider (Kassel: Bärenreiter, 1961), 3.
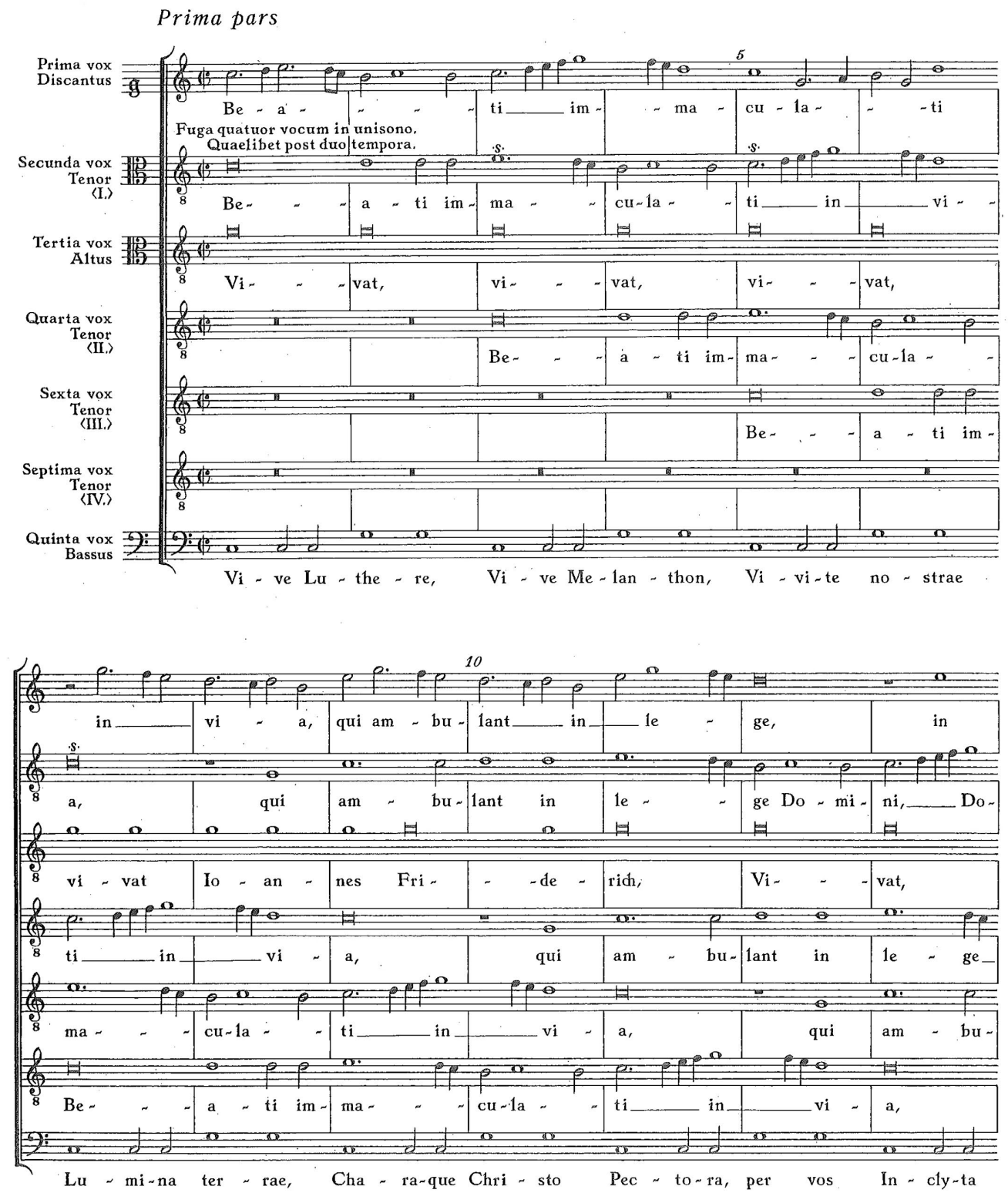
Because of its association with the biography of Martin Luther and Philipp Melanchthon, the motet has received some attention. ${ }^{56}$ August Wilhelm Ambros saw it as a peculiar occasional composition, more a 'monument' than a work of art. ${ }^{57}$ Walter Blankenburg tried to revise this idea and traced the compositional models back to Josquin des Prez and others. Among the concordant sources, the most important is the so-called Gotha Choirbook, a manuscript written for the Torgau chapel soon after its consecration, under the supervision of Johann Walter. ${ }^{58}$ The extensive choirbook transmits a rich repertoire of compositions by Walter as well as representative liturgical repertoire from mid-century. ${ }^{59}$

This choirbook also contains a sister-composition of the consecration motet, a setting of Psalm 121 for seven voices. Because of its close similarity to Walter's setting of Psalm 119, Otto Kade describes the composition, which he believed to be a unicum, as a sequel, and judged both motets as 'monstrous works of art'. ${ }^{60}$ This unfavourable interpretation has been reiterated by Walter Blankenburg, who interprets the Psalm 119 setting as Johann Walter's 'artistic Credo' ('künstlerisches Glaubensbekenntnis'). ${ }^{61}$ Jürgen Heidrich describes it as musically and artistically unsatisfying and schematic. ${ }^{62}$

The motet is a monumental work indeed. Its nine parts surpass even the motet for the Torgau festivities. However, the general architecture is nearly identical. Here too there are three different texts. The discantus and the four canonical tenor parts sing verses from the Vulgate translation of the Psalm, while bassus and altus sing sacred texts that comment on the Psalm (see Example 5.1). Again, the altus part repeats an ostinato $g^{\prime}$ for the whole piece, while the bassus alternates between $G$ and $c$. The motet's text was probably written by Johann Walter, whose name appears as an acrostic in the first letter of each verse. ${ }^{63}$ In contrast to the consecration motet, this setting has no clear connection to any specific person, institution or occasion. For a composition of these dimensions this is surprising. Especially because of its artificiality and its polytextuality, it does not fit with our expectations for devotional or liturgical music of the mid-sixteenth century.

In his comprehensive study of the life and work of Johann Walter, Blankenburg wondered why Walter did not print the composition, as he did with the Cantio. ${ }^{64}$ It appears that Blankenburg had fine instincts. While working for the $v d m$ project in the Austrian National Library in Vienna, I discovered a printed music book hitherto unknown to musicological scholarship, containing the polytextual setting of Psalm 121 by Walter known from the Gotha Choirbook. ${ }^{65}$ It is bound in an incomplete set of partbooks, directly before the printed version of Walter's consecration motet. The surviving title pages give the voice names and the words 'The Word of the Lord endureth for ever, 1545' ('Verbum domini manet in aeternum 1545', 1 Peter 1:25), a famous device of the Reformation movement, framed with a floral wreath. ${ }^{66}$ The partbook of the first and second voice, which most likely contained more detailed information about the context of the edition, is lost. There is however a colophon in all three surviving partbooks, which indicates that it was printed by Georg Rhau's workshop at Wittenberg.

There are many visual similarities with the Cantio septem vocum and other Wittenberg polyphonic music books of this time. Rhau used a familiar imagery, starting with the fonts and the woodcut ornamentation. The musical notation is printed with Rhau's singleimpression type, while the underlay is given in Roman type, as is normal in Rhau's editions. As seen in the setting of Psalm 119 for Torgau, the voices bearing either the panegyric poem or the Psalm text are printed in their respective partbooks alongside one of the canonic tenor parts. 
The most interesting aspect of the motet's printed version are major changes to the text, which shed some light on the background of our composition. The most important difference can be found in the text of the bassus part. Unlike the version in the Gotha Choirbook, which presents the composer's name as an acrostic, the printed partbook presents a political text in honour of the 'holy city whose name is derived from Anne' ('sancta retinens Urbs nomen ab Anna'), probably the Saxon city of Annaberg (see Table 5.4 in the Appendix). The first verse of the strophe is of special interest, because it is repeated in precisely the same form in the first seven parts of the composition, thus emphasising the political symbolism of the piece. In the printed version, the text expresses a prayer for peace and economic prosperity, especially for the mining industry; this desire is indicated most strongly in the sixth strophe of the text in the bassus. The theme of this prayer resonates with the opening of the Psalm, and its mountain imagery: 'I will lift up mine eyes unto the hills' ('Levavi oculos meos in montes'). A handful of places in the German-speaking lands are named after Anne, the legendary mother of Mary and patron saint of miners. However, it seems likely that Walter's motet refers to Annaberg in Saxony. In the first half of the sixteenth century, Annaberg was one of the largest cities in the region. Founded in 1496, it grew rapidly because of the flourishing silver mining industry. ${ }^{67}$ In 1540, the town had an estimated population of 12,000. (In comparison, the largest German cities, Nuremberg and Augsburg, at that time had between 20,000 and 40,000 inhabitants.) In the first decade of the town's existence, the citizens built churches, monasteries and schools under the protection of the Saxon dukes. To musicologists, Annaberg is best known for two handwritten choirbooks kept there from the early sixteenth until the twentieth century. ${ }^{68}$ The choirbooks, a collection of liturgical music from the pre-Reformation period, are the only evidence of the rich musical life of this city.

Since the main title page of the set of partbooks is missing, it is difficult to contextualise this edition. However, one might assume that the edition was prompted by a special occasion, as was the case for the 'sister-edition'. In none of the several chronicles from Annaberg which cover the 1540s could I find any indication of an event for which this version of Walter's motet plausibly might have been composed or arranged. ${ }^{69}$ The motet's text also lacks concrete contextual evidence. However, it is likely that it was composed after 1539, the year when Annaberg officially became Protestant, following the death of Georg of Saxony in the same year. The fourth strophe, which emphasising the now shining 'light of the Gospel' ('lux Evangelii'), suggests a Protestant reading. Whatever the occasion for the composition of this motet, its mere existence might be seen as an expression of the economic power and ambition of the flourishing mining town. It cannot now be determined which of the two variant texts is earlier. The handwritten choirbook from Torgau was finished in 1545, the same year the partbooks were published. Both chronologies are plausible: Walter may have adapted the political text for liturgical use in the Torgau chapel, replacing the text in praise of the city of Annaberg with a more generally appropriate one. Alternatively, he might have reworked textual elements of a sacred composition to fit the needs of an occasional publication.

The discovery of a monumental musical ovation to a city such as Annaberg supports the picture of a de-centralized cultural life in many German-speaking regions. Annaberg, as well as other cities in the Erzgebirge, was a growing urban centre with a rich musical life, as attested by the choirbooks. Johann Walter's motet thus expresses the wealth, prosperity and cultural ambition of the whole region. On the other hand, the newly discovered polyphonic edition is perfectly consistent with the economic and political agenda of Georg Rhau, who addressed many city councils in a bid to promote his products. 


\section{Lost polyphonic music books by Rhau}

The discovery of an unknown short polyphonic music book by Rhau raises another question, connected to the materiality of this kind of objects. The data collected in the vdm, VD16, and RISM databases, indicate that most occasional polyphonic music books from the time before 1550 survive in very few copies. Even the musical epitaph for Martin Luther only survives in four known exemplars (vdm 1038). The reasons for this are obvious. Firstly, the number of copies produced was probably quite low compared to nonoccasional titles, which could be sold years after production. Furthermore, because of the occasional nature of such broadsheets and small partbooks, their novelty might have worn off quickly. Sometimes the political message of a music book might have even led to their intentional destruction. Grantley McDonald distinguishes 'ephemeral' editions, intended to be consulted once or only a few times, from 'archival' publications, which were meant to be read several times. ${ }^{70}$ Occasional or ephemeral sets of partbooks celebrating a specific occasion probably have to be located somewhere in between. They embody both the ephemerality of a special occasion, and an element of archivability, since they possess the physical characteristics requisite for their inclusion as part of a composite volume. It is unclear how many such occasional music books produced in the early sixteenth century have disappeared without a trace. However, it is possible that occasional polyphonic music printing was a much larger phenomenon than is suggested by the modest surviving corpus.

An early inventory of the Ratsschulbibliothek in Zwickau contains some evidence for further lost polyphonic music from Rhau's printing workshop. The chapter listing the printed music includes a 'song for five voices by Adrianus Petit Coclico, a student of Josquin, which he composed to adorn his wedding at Wittenberg, 15 November 1545' ('Cantus quinque Vocum Adriani petit coclico. D. Josquini discipuli, quem composuit in decorem nuptiarum suarum Vitebergae anno M.D. XLV. die 15 Novemb.'). Since Rhau was the only person who printed polyphonic music books at this time in Wittenberg, he would have been the logical choice as printer for this wedding motet. ${ }^{71}$ The Zwickau catalogue lists another possible title that today might be lost: 'Song for five voices, in praise of Emperor Charles V, half a sheet' ('Carmen quinque Vocum compositum in gratiam Caroli V. Imperatoris. Ist ein halber bogen'). ${ }^{72}$ This entry may refer to a broadsheet version of a canonic composition that Rhau included in the second volume of his Bicinia. ${ }^{73}$ There is even evidence for yet more lost short polyphonic music books from the Rhau workshop. In an undated letter to Georg of Brandenburg, Johann Walter mentions that he has sent the margrave a 'printed spiritual song along with some other songs' ('gedruckt geistlich Lied neben anderem gesange'), probably a lost pamphlet, a broadsheet or even a set of short partbooks. ${ }^{74}$ Unfortunately it is impossible to say how many polyphonic music books from the Rhau printing workshop are now lost.

Our overview of Georg Rhau's polyphonic music printing must necessarily remain incomplete. In particular, the role of short polyphonic music books celebrating special occasions remains open, because of the apparently high rate of loss. Rhau was a key figure of German music printing not only because of his productivity, but also because of his political agenda. His polyphonic music books created and displayed an image of Electoral Saxon as a Lutheran stronghold. Rhau identified his work visually with Elector Johann Friedrich, Martin Luther and Philipp Melanchthon, as well as many different local 
institutions and personalities. The recently rediscovered edition, presumably dedicated to the city of Annaberg, shows that this policy extended over the borders of Ernestine Saxony to other Protestant regions. Polyphonic music books thus not only served as a medium to foster the Reformation in liturgy and domestic music, but also as a means to display a political agenda.

\section{Appendix}

Table 5.4 Bassus text of Johann Walter's setting of Psalm 121 (manuscript and printed edition in comparison)

D-Gol Chart. A 98

Ingruerent postquam violenti turbine venti, Omne fretum cepit tumidis fervere procellis Auxilio casos oculos ad culmina montis Non sine lugenti lacrimarum voce levabam, Non animi stabam dubius, quin me tua Dextra Eriperet salvumque daret, presumque levaret.

Vera mihi vis auxilii, protectio firma Vera salus, in qua liceat confidere tuto A Domino descendit ut a praedivite cornu. Larga manus, cuius fabrefecit mobile coelum Tum stabilem, fulcit a suo que pondere ${ }^{a}$ terram Hoc, mala, defensore tibi, non ullab nocebunt.

Ecce tuos gressus relegens considerat oves. Retro tuos servatque pedes ne forte ferrantur Obvia ne vel sint lubrici vestigia gressus Excubias sed semper agit custodia servans Languida nec claudit superanti lumina somno E specula servat mala ne te damna sequantur.

Concipe spes animo dubiis diffidere noli. Tutus enim cunctos poteris contemnere ventos. Otia nam nunquam petet hic secura quietis Rara nec ascendunt cerebro spiracla vaporum. Illud ut irrorent, tribuat quo tempora somno. Scilicet Israel populum, qui pace gubernat.

Sub clypeo dextrae veluti testudines quadam Atque sub alarum gracili te sustinet umbra Xysticus opponens veluti se viribus hosti Omnipotens sic dextra Dei non segnior illo est. Ne qua tibi vis vel Boreae vel turbidus Auster, Impetus aut Euri noceat vel frigora Cauri.

Aestus et excitus, gravibus squaloribus urgens Solibus aestivis, ubi findit Sirius arva Indomitus non te feriat fervoribus ardens, Menstrua nec fratris radiis obnoxia luna. Pallida cum surgit, gelida sub nocte ${ }^{\mathrm{d}}$ molestet Humida cum terrae sitienti frigora spargit.
[Motet for seven voices]. Wittenberg: Rhau, 1545

Inclyta praeclaro celebrata Urbs nomine Salve, Eximium Diva retines quae nomen ab ANNA. Salve iterum, laudes propria Virtute tuorum Quae cumulas, fama Proavos maiore decorans. Propterea nullo periturum tempore Nomen TE manet, \& multis Decus indelebile seclis.

Inclyta praeclaro celebrata Urbs nomine Salve. Aucta bonis, quae mundus habet, quae denique summus Dat Pater a celso sacra mittens munera coelo. Iusticiam amplectens colis Almae dulcia Pacis Munera, te dudum patriae iustissima tangit Cura tuae, cives placida sub Pace gubernas.

Inclyta praeclaro celebrata Urbs nomine Salve, Nam tua te Virtus celebrem, Prudentia magnam Te facit, \& sanctae Pietatis, Religionis, Iusticiae, Pacis stadium, \& pulcherrimus Urbis Ordo tuae, nunquam trepido Respublica motu Quassa labat, vivunt placida sub Pace coloni.

Inclyta praeclaro celebrata urbs nomine Salve, Cui sacra lux Evangelii nunc fulget, \& almo Sydere, propulsis redierunt sancta tenebris Dogmata, credentes animas donantia coelo. Scilicet a summo veniunt haec tanta parente Munera, quae grata veneraris mente, fovetque.

Inclyta praeclaro celebrata urbs nomine Salve, Prompta iuventuti tenerae succurrere, doctas Dum tegis, ac ornas studio non deside Musas, Paegaseos curras latices, formosus Apollo Sanctaque doctarum celebrans te turba sonorum. Tollet, \& aeterna faciet te laude decoram ${ }^{c}$.

Inclyta praeclaro celebrata Urbs nomine Salve, Te Deus aeterni cumulavit munere Verbi, Addit opes, monstrans gravida tellure metallum, Terra tibi pandit precioso viscera partu, Promit \& argenti muneroso pondere massas, Scilicet ut Musas foveas verbique ministros. 
Omnia, quae possint hominis contingere vitae Noxia, depellat removens, dispergat, et idem Ipse sub ingenti manuum te protegat umbra, Servet et indefessa tuae custodia vitae.

Te foveat, defendat, amet, custodiat, alat. Augeat, et salvet, mala ne te fata fatigent.

Ardua convertat placidos ad culmina vultus Vestibuli, servetque domus ad limina custos, Intus ut egressus, nec iter te fallat euntem Omnibus et votis referens te nocte reducat Rursus, et hoc semper faciat, dum mobile coelum Erret et ex hoc nunc et in aevi saecula cuncta.

Tam bene de me, qui meritum pro munere tali Officiis donisque datis, quae nemo referre Rite potest unquam tibi sit nunc gratia primum Gloria, maiestas honor et laus maxime divum Atque tuo nato simul et spiramine sancto Est quibus aequalis Deitas comparque potestas.
Inclyta praeclaro celebrata Urbs nomine Salve, Et sacra coelestis venereris dogmata verbi, Quod facis, \& Christi teneras cum dogmate Musas, Sic tibi non turbet placidae dulcissima pacis Tempora Mars, nullo trepidet Respublica motu, Nec metuas belli trepidanti core tumultus.

Vive vale sancta retinens Urbs nomen ab Anna, Sic vigil \& custos tua servans maenia Christus Te regat, exornans placidae te munere pacis, Floreat ut laus parta tibi virtutibus, omni Tempore, \& extollas celebris praeconia famae, Vive, vale, magno retinens Urbs nomine, nomen.

Omnipotens aeterne Deus, spes, anchora, portus, Praesidium \& virtus populo te, Christe, professo, Tempora da nostris, petimus, tranquilla diebus, Nosque sub alarum foveas, o Christe, tuarum Tegmine, ne sancto preciosi sanguinis emptis Munere, crudelis noceat vis ulla Tyranni.

The transcription follows the edition of the motet in Walter, Sämtliche Werke, 4:13-30, with reference to the manuscript source

a Edition: pendere.

b Edition: nonulla.

c Rhau: decororam.

d Edition: nocle.

\section{Notes}

1 McDonald, 'The Cult of Luther in Music', 199; Pettegree, 'Druck und Reformation neu über-

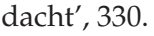

2 For the state of research see Rothe, 'Wittenberger Buchgewerbe', 79.

3 Ibid., 340-343; Pettegree, Brand Luther.

4 Reske, 'Die Anfänge des Buchdrucks', 35; Bauch, 'Wolfgang Schenck und Nicolaus Marschalk'; Grossmann, Wittenberger Drucke 1502 bis 1517.

5 Grossmann, Wittenberger Drucke 1502 bis 1517, 69.

6 Antonius Urceus, Rhythmus die divi Martini pronunciatus (Wittenberg: Johann Grunenberg, 1511), vdm 95. See McDonald, 'The Cult of Luther in Music', 206.

7 See $v d m$ (accessed 28 April 2019).

8 Woelbing, 'Der Drucker und Musikverleger Georg Rhaw'.

9 Reske, Buchdrucker, 997-998.

10 Woelbing, 'Der Drucker und Musikverleger Georg Rhaw', 12. For new details see Hennen, 'Reformation und Stadtentwicklung', 53-54.

11 Schlüter, Musikgeschichte Wittenbergs, 170-180; Heidrich, 'Georg Rhau'; Heidrich, 'Das protestantische Repertoire'; Raley, 'Traversing Borders - Defining Boundaries'; Mattfeld, Georg Rhaw's Publications for Vespers.

12 Berger, 'Noten für den Reformator'.

13 Georg Rhau, ed., Officiorum de Nativitate (Wittenberg: Georg Rhau, 1545), vdm 1035.

14 Numbers based on $v d m$ (accessed 28 April 2019). This calculation does not include all musictheory books, only those that contain musical notation, which are thus included in $v d m$.

15 First Wittenberg edition: Nicolaus Listenius, Musica (Wittenberg: Georg Rhau, 1537), vdm 559.

16 Woelbing, 'Der Drucker und Musikverleger Georg Rhaw', 23-24.

17 Krummel, 'Early German Partbook Type Faces', 82. 
18 Berger, 'Noten für den Reformator', 20-21.

19 Ibid., 42.

20 There are three exceptions to that rule: Greff, Ein Geistliches schönes newes Spil (vdm 467); Agricola, Rudimenta musices (vdm 539); Karcken Ordening (vdm 1133). vdm 467 is an undated play by Joachim Greff that might be a re-issue or predate the year 1538. For vdm 534, Martin Agricola's Rudimenta Musica, Rhau re-used woodblocks from at least one earlier vernacular music-theory book, Agricola's Ein kurtz deudsche Musica (vdm 529). vdm 1133, a church order for Pomerania, was believed to be of Wittenberg origin in the nineteenth century, although there is almost no evidence except Bugenhagen's authorisation. Judging from the printed musical notation the attribution of this publication to Rhau seems at least doubtful. (For references and an attribution to the Rostock printer Dietz, see Mohnike, Buchdruckerkunst, 132-133.)

21 Gustavson, 'Competitive Strategy Dynamics', 195.

22 Nicolaus Listenius, Rudimenta musicae (Wittenberg: Georg Rhau, 1533), vdm 552.

23 Rhau, Selectae harmoniae.

24 Heidrich, 'Georg Rhau', 198-203.

25 Johann Reusch, Epitaphia Rhauorum (Wittenberg: Georg Rhau, 1550), vdm 1154.

26 Cristóbal de Morales, Magnificat cum quatuor vocibus (Venice: Girolamo Scotto, 1542), RISM B/1 $1542^{9}$.

27 Schlüter, Musikgeschichte Wittenbergs, 147-180.

28 Ibid., 174.

29 'Semper hoc mihi summum studium fuit, prudentissimi ac ornatissimi viri, ut officina mea literaria pueris in Scholis praecipue prodessem. Quare praeteritis annis, omissis gravioribus Authoribus, tantum pro pueris artium elementa potissimum excudenda suscepi. Eadem quoque inductus ratione, nunc stanneis typis TONOS FERIALIVM PSALMORVM, ut vocant, ad Contrapunctum simpliciter variatis melodiis per quatuor voces excudere constitui, quos propter PVEROS singulis feriis in septimana exercendos, nec non Dominica die in templis cantare solemus.' Vesperarum precum officia psalmi feriarum et dominicalium dierum (Wittenberg: Georg Rhau, 1540), vdm 49 (tenor partbook), fol. A2 ${ }^{r}$. Translated by Grantley McDonald.

30 Just, 'Schalreuter', accessed on 31 January 2019.

31 Redeker, Lateinische Widmungsvorreden, 338-340.

32 Römer, 'Kling'.

33 Redeker, Lateinische Widmungsvorreden, 328.

34 Gustavson, 'Competitive Strategy Dynamics', 209.

$35 \mathrm{vdm} 40,46,49,1555,1019,1023,1024$.

$36 \mathrm{vdm} 1024,1028,1161,1162,1504$.

37 'Wollen wir uff diese kunfftige Franckfurter Herbstmes Bappir zu Biblien kauffen, auch mit Hans Lufften handeln, das er baldt nach Michaelis zu drucken anfangen soll etc. Bitten ferner E. E. W. wolle uns gunstlichen des vorzuge gegen unsern Gnedigst. Churfuerstenn und Herrn entschuldigen, auch furbitten, das ihre C. f. g. uns unser alt Priuilegium unser Bucher halben gnediglichen bestetigen wolte, uff das wir uns des nachdrucks halben nichts zubefaren hetten, Weren auch bedacht ihre C. f. g. Biltnis uffs best reissen und schneiden zu lassen, und neben das Privilegium forn, in die Biblia zu drucken, in maßen zuvorn beim alten Churfurst Hertzog Johan Friedrichen hochloblicher gedechtnis geschehen (doch mit s. c. f. g. erlaubnis) und gnedigs gefallen, seint deren trostlichen hoffnung ihre C. f. G werde uns, als ihrer c. f. g. Unterthanen gnedigst schutzen und bey unser alten Gerechtigkeit handhaben, [...] 15 Jul. Ao. 1558.' Schumacher, Gelehrter Männer Briefe, 236-237. Translated by Moritz Kelber.

38 The case of Arndt von Aich's Fünfundsiebzig hübsche Lieder (vdm 17), a woodcut reprint of at least two song collections by Peter Schöffer the Younger, shows that it was not impossible to create unauthorized reproductions of music anthologies without a single-impression font. However, Aich's is the only known example of that kind from German speaking lands in the first half of the sixteenth century. Further, see McDonald and Raninen, 'The Songbooks of Peter Schöffer the Younger'.

39 'Absoluimus hisce diebus iam praeteritis Opt. lector, in officina nostra typographica, Librum primum sacrorum Hymnorum, in quem collegimus centum \& triginta quatuor Hymnos, cum de tempore, tum de Sanctis, qui non tantum suauitate ac dulcedine, verum etiam arte ac breuitate, nec non facilitate, insignes sunt. Cum vero supremam iam manum huic operi imponeremus [...] 
venit in mentem, quam maligna hoc peruerso nostro seculo, multorum sint iuditia, qui, cum SANCTA ECCLESIA NOSTRA VVITEMBERGENSIS, inuocationes Sanctorum, atque alios Idolatricos cultus damnet, vbi viderint Hymnos de quibusdam Sanctis non conuenientes Analogiae fidei, huic nostro operi insertos, statim fortassis vociferabuntur, nos veteres impietates restaurare aut adprobare velle. Testamur igitur hoc nostro scripto, nos cum omnibus pijs execrari omnia dogmata, quae à Propheticis ac Apostolicis scriptis dissentiunt. Si qui igitur in hoc opere sunt Hymni de Sanctis, ab harmonia sacrae scripturae dissonantes, eos meminerit Lector, suauis concentus \& iuuentutis in cantu (Idolatricos enim, vt vocant, textus, nihil moramur, \& pro damnatis habemus) exercendae causa additos.' Rhau, Sacrorum hymnorum liber primus (vdm 1024), A7v. Trans. Grantley McDonald. For more information, see Redeker, Lateinische Widmungsvorreden, 306-318.

40 For an introduction into responsories and their role in the Lutheran liturgy see Leaver, Luther's Liturgical Music, 227-241; For the disagreement between Rhau and Bugenhagen see Hendrickson, Musica Christi: A Lutheran Aesthetic, 32-44.

41 Heidrich, 'Georg Rhau', 201-202.

42 Möller, 'Die beiden ältesten Notenkataloge der Ratsschulbibliothek'; Vollhardt, Bibliographie.

43 Charteris, 'A Collection of Georg Rhau's Music Editions', accessed on 31 January 2019.

44 Orf, Die Musikhandschriften, 171-175; Rautenstrauch, Luther, 204-205, 137, 67. For further information on copies of editions by Rhau in historical catalogues, see $v d m$.

45 Reske, Buchdrucker, 997-998.

46 Rhau, Magnificat octo modorum, fol. A2 ${ }^{\mathrm{r}}-\mathrm{A} 2^{\mathrm{v}}$.

47 Haug-Moritz, 'Lieder in der Flugschriftenpublizistik'.

48 Heidrich, 'Georg Rhau', 202-203; Heidrich, 'Musik und Humanismus', 106-107.

49 Johann Walter, Cantio septem vocum (Wittenberg: Georg Rhau, [1544]), vdm 1161.

50 Blankenburg, Johann Walter.

51 MacDonald, 'Walter's cantiones', 1.

52 Dunning, 'Die Staatsmotette', 161.

53 Walter, Sämtliche Werke, 4:v.

54 Blankenburg attributes these woodcuts to Lucas Cranach (although he doesn't decide for either the Elder or the Younger), Blankenburg, Johann Walter, 72.

55 The layout of the musical notation is very close to that of the other anthologies printed by Rhau the 1540 s. He does not use nesting techniques, and yet he creates a neat layout.

56 Heidrich, 'Psalmkompositionen Johann Walters'.

57 Ambros, Geschichte der Musik, 422.

58 Beside a handful of handwritten concordances, there is one other printed concordant source: Stephani, Cantiones triginta selectissimae, RISM B/I $1568^{7}$.

59 Blankenburg, 'Codex Gothanus Chart. A. 98'.

60 Kade, Luther-Codex, 38.

61 Blankenburg, Johann Walter, 280.

62 Heidrich, 'Georg Rhau', 122.

63 Editions of both motets can be found in Walter, Sämtliche Werke, 5:13-30.

64 Blankenburg, Johann Walter, 277.

65 Johann Walter, [Motet for seven voices] (Wittenberg: Georg Rhau, 1545), vdm 1517.

66 Stopp, 'Verbum Domini Manet In Aeternum'.

67 Bachmann, 'St. Annaberg', 69.

68 Kindermann, Annaberger Chorbuch I; Kindermann, Annaberger Chorbuch II; Kindermann, 'Verzeichnis von Konkordanzen'; Noblitt, 'Manuscript mus. I/D/506'.

69 Jenisch, Annaebergae [...] urbis historia (1605); Zirolt, Die Churfürstliche Süchs. freye Bergstadt St. Annabergk (mid seventeenth century); Richter, Chronica der freyen Bergstadt St. Annaberg (mid eighteenth century).

70 McDonald, 'The Cult of Luther in Music', 199.

71 Möller, 'Die beiden ältesten Notenkataloge der Ratsschulbibliothek', 23.

72 Ibid., 24.

73 Georg Rhau, ed., Secundus tomus biciniorum (Wittenberg: Georg Rhau, 1545), vdm 1036.

74 Blankenburg, Johann Walter, 76, citing Schornbaum, 'Zur Geschichte des Katechismus', 152. 


\section{References}

Ambros, August W. Geschichte der Musik, vol. 3. Leipzig: Breitkopf \& Härtel, 1881.

Bachmann, Walter. 'Die freie Bergstadt St. Annaberg'. In Sächsische Bau- und Kunstdenkmäler, edited by Landesverein Sächsischer Heimatschutz Dresden. Dresden: Graphische Kunstanstalt Liepsch \& Reichardt, 1933, 67-109.

Bauch, Gustav. 'Wolfgang Schenck und Nicolaus Marschalk'. Centralblatt für Bibliothekswesen 12 (1895): 353-409.

Berger, Daniel, et al. 'Noten für den Reformator? Zur Untersuchung der Drucktypen aus dem Wittenberger Franziskanerkloster und ihr Zusammenhang mit dem Musikaliendruck der Reformationszeit'. In Heavy Metal: bewegliche Lettern für bewegende Töne, edited by Harald Meller. Halle an der Saale: Landesamt für Denkmalpflege und Archäologie Sachsen-Anhalt, 2014, 5-67.

Blankenburg, Walter. 'Die verschlungenen Schicksalswege des Codex Gothanus Chart. A. 98. Ein kleines, absonderliches Kapitel thüringischer Bibliotheksgeschichte'. In Quellenstudien zur Musik, edited by Kurt Dorfmüller. Frankfurt: Peters, 1972, 35-40.

Blankenburg, Walter. Johann Walter: Leben und Werk. Tutzing: Hans Schneider, 1991.

Charteris, Richard. 'A Collection of Georg Rhau's Music Editions and Some Previously Unnoticed Works'. The Electronic British Library Journal 2017, http:/ / www.bl.uk/eblj/2017articles/article1.html.

Dunning, Albert. Die Staatsmotette 1480-1555. Utrecht: Oosthoek, 1970.

Grossmann, Maria. Wittenberger Drucke 1502 bis 1517. Ein bibliographer Beitrag zur Geschichte des Humanismus in Deutschland. Vienna: Krieg, 1971.

Gustavson, Royston. 'Competitive Strategy Dynamics in the German Music Publishing Industry 1530-1550'. In NiveauNischeNimbus. Die Anfänge des Musikdrucks nördlich der Alpen, edited by Birgit Lodes. Wiener Forum für ältere Musikgeschichte 3. Tutzing: Hans Schneider, 2010, $185-210$.

Haug-Moritz, Gabriele. 'Lieder in der Flugschriftenpublizistik des Schmalkaldischen Krieges'. In Kultur- und kommunikationshistorischer Wandel des Liedes im 16. Jahrhundert, edited by Albrecht Classen et al. Münster: Waxmann, 2012, 109-125.

Heidrich, Jürgen. 'Bemerkungen zu den Psalmkompositionen Johann Walters. Über humanistische Züge im nichtliturgischen Schaffen des "protestantischen Urkantors"'. In Johann-Walter-Studien, edited by Friedhelm Brusniak. Tutzing: Hans Schneider, 1998, 113-139.

Heidrich, Jürgen. 'Das protestantische Repertoire für Knaben im Umfeld der Wittenberger RhawDrucke'. In Rekrutierung musikalischer Eliten: Knabengesang im 15. und 16. Jahrhundert, edited by Nicole Schwindt. Trossinger Jahrbuch für Renaissancemusik 10 (2011): 143-156.

Heidrich, Jürgen. 'Georg Rhau als Wittenberger Musikaliendrucker und -verleger'. In Buchdruck und Buchkultur im Wittenberg der Reformationszeit, edited by Stefan Oehmig. Schriften der Stiftung Luthergedenkstätten in Sachsen-Anhalt 21. Leipzig: Evangelische Verlagsanstalt, 2015, 191-203.

Heidrich, Jürgen. 'Musik und Humanismus an der Fürstenschule St. Afra zu Meissen'. In Musikalische Quellen - Quellen zur Musikgeschichte. Festschrift für Martin Staehelin zum 65. Geburtstag, edited by Ulrich Konrad. Göttingen: Vandenhoeck \& Ruprecht, 2002, 97-109.

Hendrickson, Marion Lars. Musica Christi. A Lutheran Aesthetic. New York: Lang, 2005.

Hennen, Insa C. 'Reformation und Stadtentwicklung. Einwohner und Nachbarschaften'. In Das ernestinische Wittenberg: Stadt und Bewohner. Textband, edited by Heiner Lück et al. WittenbergForschungen 2.1. Petersberg: Michael Imhof, 2013, 33-76.

Jenisch, Paul. Annaebergae Misniae urbis historia in duos libros digesta. Dresden: Hieronymus Schütz, 1605.

Just, Martin. 'Schalreuter'. In MGG Online (2016). https:/ /www.mgg-online.com/mgg/stable/25958. 
Kade, Otto. Der neuaufgefundene Luther-Codex vom Jahre 1530. Dresden: Klemm, 1871.

Kindermann, Jürgen, ed. Annaberger Chorbuch I: Sächsische Landesbibliothek Mus. 1-D-505 (Ms. 1248). Wiesbaden: Breitkopf \& Härtel, 2017.

Kindermann, Jürgen, ed. Annaberger Chorbuch II: Sächsische Landesbibliothek Mus. 1-D-506 (Ms. 1126). Wiesbaden: Breitkopf \& Härtel, 2010.

Kindermann, Jürgen. 'Verzeichnis von Konkordanzen zu Kompositionen aus den Annaberger Chorbüchern Ms. 1126 and Ms. 1248'. Die Musikforschung 27 (1974): 86-92.

Krummel, Donald W. ‘Early German Partbook Type Faces'. Gutenberg-Jahrbuch 60 (1985): 80-98.

Leaver, Robin. Luther's Liturgical Music. Prinicples and Implications. Grand Rapids, MI and Cambridge: Wm. B. Eerdmans, 2007.

MacDonald, Alan. 'Johann Walter's cantiones (1544): Historical Background and Symbolic Influences'. Masters thesis, University of British Columbia, 1995.

Mattfeld, Victor H. Georg Rhaw's Publications for Vespers. Musicological Studies 11. New York: Institute of Mediaeval Music, 1966.

McDonald, Grantley. 'The Cult of Luther in Music'. In Early Music Printing in German-Speaking Lands, edited by Andrea Lindmayr-Brandl, Elisabeth Giselbrecht and Grantley McDonald. London and New York: Routledge, 2018, 199-224.

McDonald, Grantley, and Sanna Raninen. 'The Songbooks of Peter Schöffer the Younger and Arnt von Aich: A Typographical Assessment', in Senfl-Studien III, edited by Stefan Gasch and Sonja Tröster. Wiener Forum für ältere Musikgeschichte 9. Vienna: Hollitzer Verlag, 2019, 29-53.

Möller, Eberhard. 'Die beiden ältesten Notenkataloge der Ratsschulbibliothek Zwickau'. In Festschrift Haberkamp, edited by Paul Mai. Tutzing: Hans Schneider, 2002, 13-26.

Mohnike, Gottlieb. Die Geschichte der Buchdruckerkunst in Pommern. Stettin: August Ferdinand Bülow, 1840.

Noblitt, Thomas L. 'Manuscript mus. I/D/506 of the Sächsische Landesbibliothek, Dresden ("Olim" Annaberg, Bibliothek der St. Annenkirche, Ms. 1126)'. Musica disciplina 28 (1974): 81-127.

Orf, Wolfgang. Die Musikhandschriften der Thomaskirche Mss. 49/50 und 51 in der Universitätsbibliothek in Leipzig. Leipzig: Deutscher Verlag für Musik, 1966.

Pettegree, Andrew. Brand Luther: 1517. Printing, and the Making of the Reformation. New York: Penguin, 2015.

Pettegree, Andrew. 'Druck und Reformation neu überdacht - ein Blick von außen'. In Buchdruck und Buchkultur im Wittenberg der Reformationszeit, edited by Stefan Oehmig. Wittenberg: Evangelische Verlagsanstalt, 2015, 329-347.

Raley, J. Michael. 'Traversing Borders - Defining Boundaries: Cosmopolitan Harmonies and Confessional Theology in Georg Rhau's Liturgical Publications'. The Sixteenth Century Journal 43/4 (2012): 1079-1105.

Rautenstrauch, Johannes. Luther und die Pflege der kirchlichen Musik in Sachsen. Leipzig: Breitkopf \& Härtel, 1907.

Redeker, Raimund. Lateinische Widmungsvorreden zu Mess- und Motettendrucken der ersten Hälfte des 16. Jahrhunderts. Schriften zur Musikwissenschaft aus Münster 6. Eisenach: Wagner, 1995.

Reske, Christoph. 'Die Anfänge des Buchdrucks im vorreformatorischen Wittenberg'. In Buchdruck und Buchkultur im Wittenberg der Reformationszeit, edited by Stefan Oehmig. Wittenberg: Evangelische Verlagsanstalt, 2015, 35-69.

Reske, Christoph. Die Buchdrucker des 16. und 17. Jahrhunderts im deutschen Sprachgebiet, aufder Grundlage des gleichnamigen Werkes von Josef Benzing. 2nd edition. Beiträge zum Buch- und Bibliothekswesen 51. Wiesbaden: Harrassowitz, 2015. 
Rhau, Georg: Responsorium numero octoginta. 2 vols, edited by Inge-Maria Schröder. Georg Rhau Musikdrucke aus den Jahren 1538-1545 in praktischer Neuausgabe 1/2. Kassel: Bärenreiter, 1955/1957.

Rhau, Georg: Selectae harmoniae de Passione Domini, edited by Wolfgang Reich. Georg Rhau. Musikdrucke aus den Jahren 1538-1545 in praktischer Neuausgabe 10. Kassel: Bärenreiter, 1990.

Richter, Adam Daniel; Willy Roch (reviser). Chronica der freyen Bergstadt St. Annaberg im Erzgebirge. Regensburg: Korb'sches Sippenarchiv, 1977.

Römer, Christof. 'Kling, Melchior'. In Neue Deutsche Biographie, vol. 12. Berlin: Duncker \& Humbolt, 1980, 76-77.

Rothe, Vicky. 'Wittenberger Buchgewerbe und -handel im 16. Jahrhundert'. In Das ernestinische Wittenberg: Stadt und Bewohner. Textband, edited by Heiner Lück et. al. Wittenberg-Forschungen 2.1. Petersberg: Michael Imhof, 2013, 77-90.

Schlüter, Melanie. Musikgeschichte Wittenbergs im 16. Jahrhundert: Quellenkundliche und sozialgeschichtliche Untersuchungen. Göttingen: V\&R unipress, 2010.

Schornbaum, Karl. 'Zur Geschichte des Katechismus im Fürstentum Brandenburg-Ansbach'. Zeitschrift für bayerische Kirchengeschichte 9 (1934): 149-152.

Schumacher, Andreas. Gelehrter Männer Briefe an die Könige in Dänemark vom Jahr 1522 bis 1663. Copenhagen and Leipzig: Friedrich Christian Pelt, 1758.

Stopp, Frederic John. 'Verbum Domini Manet In Aeternum - The Dissemination of a Reformation Slogan'. In Essays in German Language, Culture and Society, edited by Siegbert Salomon Prawer et al. London: Institute of Germanic Studies, 1969, 123-135.

Vollhardt, Reinhard. Bibliographie der Musik-Werke in der Ratsschulbibliothek zu Zwickau. Leipzig: Breitkopf \& Härtel, 1896.

Walter, Johann: Sämtliche Werke. Vol. 4, edited by Max Schneider. Kassel: Bärenreiter, 1973.

Walter, Johann: Sämtliche Werke. Vol. 5, edited by Max Schneider. Kassel: Bärenreiter, 1961.

Woelbing, Willy. 'Der Drucker und Musikverleger Georg Rhaw: Ein Beitrag zur Drucker- und Verlagstätigkeit im Zeitalter der Reformation'. PhD dissertation, Friedrich-Wilhelm-Universität Berlin, 1922.

Zirolt, Michael; Helmut Unger (reviser). Die Churfürstliche Sächs. freye Bergstadt St. Annabergk: chronikalische Aufzeichnungen über Annaberg und das Bergwerk. Streifzüge durch die Geschichte des oberen Erzgebirges. Annaberg-Buchholz: Arbeitskreis 'Annaberg-Buchholzer Heimatforscher', 2000. 